\title{
Parentesco de nação: vestípios de uma Comunidade Africana em Rio Grande
}

Jovani de Souza Scherer*

Resumo. Este trabalho investiga as experiências de busca de liberdade empreendidas por escravos e libertos no município de Rio Grande, no extremo sul do Império brasileiro, durante o século XIX. Ao contrário do observado para outras regiões brasileiras, em Rio Grande os nascidos na África tiveram mais sucesso que os nascidos no Brasil em se libertar da escravidão. Na configuração desse quadro foi fundamental a ação da comunidade de africanos ocidentais. Minas e nagôs constituíram parte substancial da população africana da cidade portuária sulina, reorganizaram suas vidas em torno do parentesco de nação, alcançando a hegemonia do mercado da liberdade entre os africanos, através da compra de suas alforrias.

Palavras-chave: Liberdade. Comunidade Africana. Africanos Ocidentais

A reconstituição de trajetórias de vida de africanos tem trazido, recentemente, contribuições para a compreensão da experiência dos homens e das mulheres retirados à força da sua terra natal na África e escravizados no sul do Brasil. Esses estudos buscam uma recomposição possível dos percursos de pessoas que passaram sua vida de maneira relativamente anônima, algumas com papéis

* Mestre em História pela UNISINOS. E-mail: jovanscherer@ yahoo.com.br

Anos 90, Porto Alegre, v. 15, n. 27, p.189-231, jul. 2008 
Parentesco de nação: vestígios de uma comunidade...

destacados na reorganização da comunidade africana e negra na diáspora, outras nem tanto. Entretanto, essas experiências individuais revelam aspectos desconhecidos nas páginas da história dessas populações e podem nos auxiliar, testando e melhor compreendendo as pesquisas quantitativas. ${ }^{1}$

Tais trabalhos estudam trajetórias de africanos escravizados e trazidos para o Brasil e têm em comum as inevitáveis lacunas nas fontes, assim como igualmente lacunar é a trajetória aqui apresentada do africano Jorge Cipriano Rodrigues Barcelos. Por outro lado, mesmo cheio de pontos de interrogação, o resgate da história desses personagens quase anônimos "permite, antes de mais nada, mostrá-los como agentes da própria história” (MAMIGONIAN, 2004, p. 46).

Originalmente concebido como parte do último capítulo de minha dissertação de mestrado, o texto que segue trata das possibilidades de relações de parentesco de nação entre africanos ocidentais na região de Rio Grande, a partir de fragmentos da vida em liberdade de um africano.

\section{A população africana em Rio Grande}

O africano Jorge viveu durante o século XIX na cidade do Rio Grande, lugar onde encontrou uma numerosa população trazida à força da África, com a qual pôde estabelecer laços de solidariedade, recriando e reinventando tradições daquele continente, apesar das agruras impostas pelo sistema escravista.

Os nascidos na África constituíam 55\% dos escravos desta cidade portuária, listados nos inventários post-mortem abertos em anos ímpares entre 1825 e 1865. Entre os alforriados, eram proporcionalmente superiores aos crioulos, variando entre $65 \%$ das alforrias notariais e cerca de $60 \%$ das testamentárias. ${ }^{2}$ Isso significa que os africanos alforriavam-se de $10 \%$ a $5 \%$ a mais do que sua 
proporção na população escrava, enquanto que os crioulos constituíam cerca de $45 \%$ da população escrava e alforriavam-se entre 35\% e $40 \%$, nas alforrias notariais e testamentárias, respectivamente.

A supremacia africana, contudo, nem sempre ocorreu. Antes de 1830, os africanos recebiam alforrias em proporções menores às que eram encontradas entre os escravos, embora muito próximas. Eles eram cerca de 58\% dos libertos e 60\% dos escravos, ou seja, uma diferença de apenas 2\%. Pode-se dizer que as alforrias nesse período estavam de acordo com as proporções de crioulos e africanos entre os escravos e que nenhum desses se destacava no "jogo da alforria".

A década de trinta do oitocentos, foi quando os africanos passaram a se alforriar em número proporcionalmente superior ao que era encontrado entre os escravos. Permaneciam sendo cerca de 61\% dos cativos, mas passaram a constituir 69\% dos alforriados, oito pontos percentuais a mais do que na população escrava. Após 1850, a porcentagem de africanos alforriados diminuiu, passaram a ser 64\%; no entanto, sua presença entre os escravos se reduziu mais, eram cerca de 50\% deles. Assim, após 1850, os africanos passaram a adquirir, proporcionalmente, ainda mais alforrias, pois a diferença da presença deles entre alforriados e escravos passava a ser quatorze pontos percentuais. Os crioulos tiveram sua presença aumentada entre a população escrava e diminuída na liberta de modo inversamente proporcional aos africanos. A partir da década de 1830 eram, 39\% dos escravos e 31\% dos libertos. De 1850 até 1865, os crioulos tornaram-se metade $(50 \%)$ dos cativos, mas as alforrias chegaram em suas mãos apenas em $36 \%$ dos casos. ${ }^{3}$

Uso o termo adquiriam especialmente para os africanos, em razão de eles comprarem proporcionalmente mais suas alforrias que os crioulos. Talvez seja possível afirmar que o maior número de alforrias em mãos africanas seja conseqüência direta das cartas de liberdade pagas que esses conquistavam. ${ }^{4}$ 
Com efeito, cruzando a origem e o sexo dos alforriados com o motivo das alforrias (Tabela 1), percebe-se que os africanos, sem diferenças significativas entre os sexos, compravam em torno de $60 \%$ das suas alforrias. Entre os crioulos, de modo distinto, os do sexo masculino compravam cerca de $30 \%$ das suas alforrias, enquanto $45 \%$ das cartas de liberdade conferidas às mulheres eram adquiridas mediante pagamento.

\section{Tabela 1 - Origem e Sexo dos libertos pelo tipo de alforria}

\begin{tabular}{l|c|c|c|c|c|c|c|c|}
\multirow{2}{*}{ Tipos } & \multicolumn{4}{c|}{ Crioulos } & \multicolumn{4}{c|}{ Africanos } \\
\cline { 2 - 10 } & \multicolumn{2}{|c|}{$\mathrm{H}$} & \multicolumn{2}{c|}{$\mathrm{M}$} & \multicolumn{3}{c|}{$\mathrm{H}$} & \multicolumn{3}{c|}{$\mathrm{M}$} \\
\cline { 2 - 10 } & $\mathrm{n}^{\circ}$ & $\%$ & $\mathrm{n}^{\circ}$ & $\%$ & $\mathrm{n}^{\circ}$ & $\%$ & $\mathrm{n}^{\circ}$ & $\%$ \\
\hline Paga & 19 & 30,16 & 58 & 46,03 & 101 & 60,12 & 119 & 62,3 \\
\hline Condicional & 18 & 28,57 & 24 & 19,05 & 31 & 18,45 & 20 & 10,48 \\
\hline $\begin{array}{l}\text { Sem obrigação } \\
\text { ou condição }\end{array}$ & 24 & 38,1 & 44 & 34,92 & 35 & 20,83 & 51 & 26,7 \\
\hline Desconhecida & 2 & 3,17 & 0 & 0 & 1 & 0,6 & 1 & 0,52 \\
\hline Subtotal & 63 & 100 & 126 & 100 & 168 & 100 & 191 & 100 \\
\hline Total & \multicolumn{3}{|c|}{189} & & \multicolumn{5}{|c|}{359} \\
\hline
\end{tabular}

Fonte: APERS, Livros Notariais de Rio Grande 1812-1865

De acordo com esse quadro, os crioulos eram proporcionalmente mais favorecidos nas alforrias não pagas, naquelas em que recebiam alforria condicionada ao cumprimento das mais variadas condições, em especial a prestação de serviços, mas sobretudo nas alforrias em que o proprietário não explicitava condição ou ônus algum no texto da carta.

Antes de interpretar o número maior de alforrias que os africanos recebiam como um favorecimento do sistema a eles, se deve valorizar sua capacidade de acumular pecúlio e adquiri-las. Em outras palavras, o número elevado de alforrias pagas revela que os africanos conseguiam, de forma efetiva, comprar sua liberdade, apesar das dificuldades que o sistema escravista lhes impunha. 
As diferenças observadas entre africanos e crioulos nas formas de aquisição da alforria demonstram, em última instância, que os cativos eram agentes de sua própria história e, como tais, suas características sexuais e de origem implicavam decisivamente as suas possibilidades de liberdade, ora facilitando, ora dificultando a maneira como passavam à condição de libertos. Este texto é dedicado a compreender como os africanos ocidentais que viveram em Rio Grande se organizavam na busca pela tão sonhada alforria.

\section{Uma concepção política de identidade étnica}

Sem intenção de abordar toda a extensa bibliografia sobre as questões relativas a identidades étnicas africanas no Brasil Imperial e Colonial, propõe-se aqui uma breve introdução sobre a temática, passando por uma leitura de alguns dos principais autores que vêm trabalhando essa questão vinculada ao período escravista.

Conforme Alberto da Costa e Silva, o tráfico de escravos foi o grande vínculo que se estabeleceu entre os dois lados do Atlântico. Entretanto, esse movimento não se restringia somente às margens da África e da América, mas atingia até populações do interior dos dois continentes. Africanos no Brasil e brasileiros na África estavam em contato permanente pela rede de comunicação que se estabeleceu a partir de marinheiros, comerciantes e exescravos que atravessavam freqüentemente o oceano ligando as suas margens, levando e trazendo notícias sobre parentes e acontecimentos que envolviam suas terras natais (SILVA, 2003, p. 54-55).

Costa e Silva criticou duramente a historiografia brasileira que, por quase um século, se manteve indiferente à importância (ou influência) da África para se entender o Brasil. A grande exceção foi Nina Rodrigues. Este autor, que fez suas observações na virada do século XIX para o XX, já indicava qual seria a maior dificuldade 
Parentesco de nação: vestígios de uma comunidade...

dos pesquisadores da temática, atualmente: a discrepância entre os etnômios dos grupos africanos em seu ambiente natal e os observados no Brasil (RODRIGUES, 1976, p.102).

Nos últimos anos, no entanto, a historiografia brasileira da escravidão tem buscado corrigir esse defeito de perspectiva que a marcou por anos e passou a demonstrar que o escravo não havia "nascido no navio negreiro" (SILVA, 2003, p. 78-79). Quer dizer, os africanos traficados para o Brasil traziam consigo toda uma bagagem cultural, que orientava os mais diversos aspectos de sua reorganização social.

Sob essa perspectiva, as identidades africanas foram inventadas, transformadas, reorganizadas e redefinidas na América ${ }^{5}$. A metamorfose começava no momento da captura e retirada da terra natal, passando pela importante experiência da travessia do atlântico, amontoados em navios superlotados, depositados nos ambientes mais insalubres, onde começaram a forjar um forte sentimento de solidariedade diante de tamanho infortúnio, criando (ou ressignificando) inclusive uma palavra para designar o companheiro dessa mesma experiência: Malungu (SLENES, 1991-2) ${ }^{6}$.

O estudo de Thornton (2004, p. 48) sobre a África demonstra que "os africanos foram participantes ativos no mundo atlântico, tanto no comércio africano (inclusive no comércio de escravos) quanto como escravos no Novo Mundo". As novas identidades surgidas na América eram também baseadas em lógicas africanas. Elas parecem ser fruto do contato entre africanos e europeus, e ,mais tarde, de americanos, estabelecido no comércio e produção de escravos provenientes da África, misturando nomes de portos, línguas e de regiões africanas com designações étnicas de abrangências diversas.

Para Maria Inês Côrtes de Oliveira, as "nações" africanas do Novo Mundo não guardavam uma correspondência com as formas como eram nomeados os grupos africanos. A autora verificou que na Bahia, "os nomes de nação" "atribuídos aos africanos no circuito do tráfico negreiro terminaram por ser assumidos por aqueles como verdadeiros etnômios no processo de organização de suas comunidades". 
Esta autora sugere que o fato mesmo de os "nomes de nação" aqui observados não corresponderem aos na África, facilitaria o processo de aceitação pelos africanos desses novos etnômios, pois não entravam em conflito com seus sistemas anteriores, o que permitia a eles que os mantivessem. Outro ponto seria que, por se reportarem a realidades geográficas e culturais amplas, as novas identidades permitiam aos africanos estabelecer alianças, criando "novos meios de organização coletiva" no Brasil. (OLIVEIRA, 1995/ 96, p. 175-176).

Gomes, Libano Soares e Farias perceberam esses novos modos de organização coletiva dos africanos como uma expressão da concepção política dessas novas identidades. Estes autores lembram que as construções étnicas africanas devem sempre ser levadas em consideração pelo estudioso, mas fundamental é "avançar na compreensão das visões dos africanos em contextos específicos, perscrutando signos e significados políticos das identidades 'africanas' na condição escrava"’ . Quer dizer, as nações africanas foram identidades políticas organizadas mais na experiência do cativeiro do que em uma origem comum na África. Esta concepção da identidade africana - mais política do que étnica - é a mais apropriada ao entendimento do papel da identidade mina-nagô em Rio Grande.

Interessante perceber, nesse sentido, a posição desta cidade portuária sulina no tráfico transatlântico de escravos. Se a experiência da travessia do oceano era marcante na formação de uma identidade comum aos africanos, aqueles remetidos para o sul do Império brasileiro passavam por mais uma viagem, que poderia ser executada por terra, mas que era fundamentalmente empreendida por via marítima.

O porto de Rio Grande se localizava na chamada terceira perna desse comércio; portanto, os africanos ali aportados eram enviados de outras cidades portuárias brasileiras como Rio de Janeiro, Recife e Salvador (BERUTE, 2006). Estes cativos passavam por mais uma experiência de viagem, alguns - os ladinos, provavelmente - tendo novamente redes pessoais e parentais rompidas. 
Parentesco de nação: vestígios de uma comunidade...

Conforme Mariza Soares, mesmo a "nação" sendo inicialmente uma atribuição do tráfico negreiro, ela:

acaba sendo incorporada pelos grupos organizados no cativeiro e servindo como ponto de referência tanto para o reforço de antigas fronteiras étnicas e territoriais, como para o estabelecimento de novas configurações identitárias, sejam elas étnicas ou não. Por isso, mesmo quando indivíduos de um mesmo grupo étnico, língua ou cultura predominam no interior de uma 'nação', esta não corresponde a um grupo étnico. As nações são categorias identitárias que operam faz̧endo uso das configurações étnicas mas não são, elas mesmas, grupos étnicos. Grifos meus. (SOARES, 2004, p.308).

Se, de certa forma, há um consenso sobre a importância de costumes e práticas africanas entre escravos e libertos, o mesmo não pode ser dito sobre a constituição de comunidades africanas. Segundo Sheila Faria, a maior divergência está:

na questão de se a vida cotidiana e as formas de adaptação ou resistência ao cativeiro criaram comunidades com identidades e solidariedades próprias, apesar da multiplicidade étnica existente, ou se as rivalidades foram tão preponderantes que provocaram a dissensão, impedindo a formação de alianças que lhes dessem maior força no embate com os senhores. (FARIA, 2004, p. 39-40).

De acordo com a autora, o debate é polarizado; de um lado, Florentino e Góes e Hebe Mattos e, do outro, Robert Slenes. Florentino e Góes defendem que a entrada constante de novos africanos de origens étnicas diversas provocara muito mais a dissensão entre os cativos do que a unidade (FLORENTINO; GÓES, 1997). As rivalidades entre os grupos africanos teriam impedido o surgimento de solidariedades que resultassem na formação de uma comunidade. 
Hebe Mattos argumenta que, apesar de haver possibilidade de superação das diferenças étnicas, as rivalidades observadas na disputa por recursos fariam com que os escravos privilegiados vivessem próximos do nível de livres pobres, além de encontrarem uma maior facilidade no acesso à alforria (MATTOS, 1998). A disputa por recursos impediria a coesão e a formação da comunidade; haveria, por isso, mais diferenciação entre os cativos do que solidariedades (FARIA, 2004, p.41).

Slenes (1999), ao visualizar a proto-nação banto no Sudeste, discordou que houvesse entre os cativos africanos um estado permanente de conflito, na primeira metade do XIX. As similaridades lingüísticas e culturais permitiriam a identificação e a formação de comunidades escravas. "Para o autor, tanto formando famílias quanto sofrendo a mesma disciplina nas fazendas, os africanos, enquanto escravos, teriam forjado mais sociabilidade e solidariedade do que dissensão" (FARIA, 2004, p. 43-44).

A identidade africana a que Slenes se refere não era uma permanência da original africana. Principalmente nas áreas rurais, a identidade banto não se manteria como outrora existira na África. Segundo o autor, na cidade do Rio os africanos encontravam chances maiores do que no campo de se "circundarem com fragmentos de suas sociedades de origem". A predominância de crianças no tráfico após 1811 teria contribuído para a transculturação entre africanos; quer dizer, por serem muito novos, os jovens africanos traficados para o Sudeste brasileiro teriam incorporado noções básicas de suas culturas originais, não sendo instruídos nos aspectos mais específicos. Isto facilitaria "a superação de fronteiras étnicas antigas e a formação de uma nova identidade "bantu"' (SLENES, 1991-92, p. 56-58).

O predomínio de grupos africanos bantos, entretanto, não se observa para todas as regiões do Brasil. Nina Rodrigues já questionara o exclusivismo desses africanos no Brasil, forma pela qual seriam citados na virada do século XIX para o XX: 
Parentesco de nação: vestígios de uma comunidade...

A crença que domina os cientistas pátrios é que foram bantos os povos negros que colonizaram o Brasil. No erro deste exclusivismo incidem etnólogos, historiadores e literatos. E é talvez a grande autoridade de Spix e Martius, que mais o tem valido e propagado.[...]. Para eles, dos congos, cabindas e angolas na Costa ocidental da África, dos macuas e anjicos na oriental, provieram todos os africanos brasileiros. (RODRIGUES, 1976, p. 18-19).

Não se deve cair no mesmo erro e supor que a população africana do Rio Grande do Sul fosse quase exclusivamente banto, sem a comprovação das fontes. A evolução do quadro da população africana de Rio Grande, a partir da observação de inventários postmortem e cartas de alforrias notariais, indica que a população afroocidental cresceu ao longo do século XIX e que, nas últimas décadas do período escravista (após 1865), poderia até predominar entre os escravos africanos, já que entre os libertos eles já eram hegemônicos desde as décadas de 1830 e 1840.

O acréscimo de ocidentais entre cativos e libertos teve uma data chave: 1835, ano do levante malê na Bahia. Após essa data, minas e nagôs se multiplicaram e, trinta anos após a trágica revolta africana no nordeste do Brasil, eles eram hegemônicos entre os africanos que se alforriavam no sul do império e, entre os cativos, também alcançavam presença substancial.

As duas tabelas a seguir demonstram esses movimentos. $\mathrm{Na}$ primeira, são listadas as regiões da África de onde procediam os escravos e, na seguinte, os alforriados. O cruzamento das duas permite a comparação da atuação desses grupos na aquisição de alforrias em parte do oitocentos. 


\section{Tabela 2A - Regiões da África entre escravos africanos em três momentos}

\begin{tabular}{|l|c|c|c|c|c|c|c|c|}
\hline Região da África & \multicolumn{1}{|c}{$1810-1830$} & \multicolumn{2}{c|}{$1831-1850$} & \multicolumn{2}{c|}{$1851-1865$} & \multicolumn{3}{c|}{ Total } \\
\hline & $\mathrm{n}^{\circ}$ & $\mathbf{\%}$ & $\mathrm{n}^{\circ}$ & $\mathbf{\%}$ & $\mathrm{n}^{\circ}$ & $\mathbf{\%}$ & $\mathrm{n}^{\circ}$ & $\%$ \\
\hline Ocidental & 12 & $\mathbf{1 1 , 2 1}$ & 71 & $\mathbf{2 2 , 0 5}$ & 143 & $\mathbf{4 2 , 0 6}$ & 226 & 29,39 \\
Central Atlântica & 88 & $\mathbf{8 2 , 2 5}$ & 215 & $\mathbf{6 6 , 7 7}$ & 162 & $\mathbf{4 7 , 6 5}$ & 465 & 60,47 \\
Oriental & 7 & $\mathbf{6 , 5 4}$ & 36 & $\mathbf{1 1 , 1 8}$ & 35 & $\mathbf{1 0 , 2 9}$ & 78 & 10,14 \\
\hline Total & 107 & $\mathbf{1 0 0}$ & 322 & $\mathbf{1 0 0}$ & 340 & $\mathbf{1 0 0}$ & 769 & 100 \\
\hline
\end{tabular}

Fonte: APERS, RG, Inventários post-mortem, 1825-1865.

\section{Tabela 2B - Regiões da África entre africanos alforriados em três momentos}

\begin{tabular}{|l|c|c|c|c|c|c|c|c|}
\hline Região da África & \multicolumn{3}{|c}{$1810-1830$} & \multicolumn{1}{c|}{$1831-1850$} & \multicolumn{2}{c|}{$1851-1865$} & \multicolumn{3}{c|}{ Total } \\
\hline & $\mathrm{n}^{\circ}$ & $\mathbf{\%}$ & $\mathrm{n}^{\circ}$ & $\mathbf{\%}$ & $\mathrm{n}^{\circ}$ & $\mathbf{\%}$ & $\mathrm{n}^{\circ}$ & $\mathbf{\%}$ \\
Ocidental & 9 & $\mathbf{1 5 , 7 9}$ & 89 & $\mathbf{5 6 , 6 9}$ & 85 & $\mathbf{7 7 , 2 7}$ & 183 & $\mathbf{5 6 , 4 8}$ \\
Central Atlântica & 48 & $\mathbf{8 4 , 2 1}$ & 65 & $\mathbf{4 1 , 4}$ & 22 & $\mathbf{2 0}$ & 135 & $\mathbf{4 1 , 6 7}$ \\
Oriental & - & - & 3 & $\mathbf{1 , 9 1}$ & 3 & $\mathbf{2 , 7 3}$ & 6 & $\mathbf{1 , 8 5}$ \\
\hline Total & 57 & $\mathbf{1 0 0}$ & 157 & $\mathbf{1 0 0}$ & 110 & $\mathbf{1 0 0}$ & 324 & $\mathbf{1 0 0}$ \\
\hline
\end{tabular}

Fonte: APERS, RG, Livros Notariais, 1812-1865.

Como certa vez argumentou Schwartz (2001, p. 188), a origem dos africanos expressa tendências gerais do tráfico. Assim, pode-se dizer que foi na época do tráfico ilegal de africanos que os ocidentais passaram a ser substancialmente representativos entre os cativos importados pela Província de São Pedro. Após 1850, os afroocidentais passaram a constituir mais de $40 \%$ dos escravos africanos; contudo, isso também poderia estar relacionado ao decréscimo natural (através da morte) de africanos da região Central-Atlântica da África, os quais, na sua grande maioria, devem ter chegado antes dos primeiros a Rio Grande.

Entretanto, o aumento populacional dos cativos afro-ocidentais entre os cativos não explica totalmente os altos índices destes entre a população alforriada. Apenas na primeira parcial eles alcançavam alforrias em números aproximados à sua presença entre os cativos, com 11,21\% dos cativos e 15,79\% dos alforriados. Nas duas parciais seguintes, entre 1831 e 1850 e entre 1851 e 1865, eles passaram 
a dominar o mercado de alforrias. Eram, na primeira, 22,05\% dos cativos e $56,69 \%$ dos alforriados e, na seguinte, $42,06 \%$ dos escravos e $77,27 \%$ dos africanos que receberam carta de liberdade.

A alternativa encontrada para procurar elementos que explicassem a desproporção de ocidentais entre a população escrava e liberta, em termos empíricos e não apenas hipotéticos (através da bibliografia sobre o tema), foi a pesquisa das experiências cotidianas dos africanos ocidentais. Nessa procura foram encontrados vários casos relevantes, em especial Jorge Cipriano Rodrigues Barcelos, preto forro de nação mina-nagô. Ele apareceu como ponto em comum, elo entre vários indivíduos das nações mina, nagô, haussá e jeje.

Nesse intento, procura-se seguir a sugestão "de que qualquer teoria a respeito da demografia da escravidão, como aliás, sobre qualquer aspecto minimamente importante dessa instituição, terá de levar em consideração os projetos e estratégias dos escravos." (SLENES, 1999, p. 203). Quer dizer, ao analisar experiências cotidianas de africanos, procurou-se seus projetos e estratégias que implicassem a conquista da alforria. Os fragmentos da vida de Jorge aqui reunidos indicam a formação de uma comunidade de africanos ocidentais na cidade de Rio Grande em torno do objetivo comum de liberdade.

\section{A vida em liberdade do africano Jorge Cipriano Rodrigues Barcelos}

Suas experiências como escravo antes de 1839 ainda são desconhecidas. Entretanto, esse homem teve vários momentos de sua vida documentados durante os quarenta anos que separam o registro de sua carta de alforria, em 1839, e o seu testamento, em 1879. Em todas as ocasiões em que teve fragmentos de sua vida registrados, ele estava cercado por africanos, especialmente de minas e nagôs, mas também de haussás e jejes. Procura-se sanar 
parcialmente as lacunas da documentação sobre Jorge usando outros casos envolvendo indivíduos com experiências sociais semelhantes à sua, que, assim como ele, eram pretos forros, africanos de nação mina ou nagô.

Em 14 de agosto de 1839, teve sua carta de liberdade concedida pelo Comendador Cipriano Rodrigues Barcelos. O texto do documento apenas afirma que o preço pago por Jorge havia sido o valor pelo qual o seu senhor o "estimava”, e que Jorge era preto, de nação Mina. ${ }^{8}$

Ainda se desconhece se o Comendador tinha negócios em Rio Grande, sabe-se apenas que parte significativa de seus bens estava situada em Pelotas, local por onde correu seu inventário post-mortem, em 1869. ' É possível que Jorge houvesse migrado para Rio Grande e lá registrado sua alforria. De acordo com Hebe Mattos (1998, p. 31), na segunda metade do século XIX, quando já eram mais numerosos na população, os não-brancos livres realizavam a mobilidade espacial, preferencialmente entre áreas próximas, freqüentemente entre freguesias vizinhas - como Pelotas e Rio Grande -, o que a tornava restrita, mas não interdita a eles.

Passados sete anos, Jorge novamente emerge na documentação. Em 1846, esse africano que já passara da condição de cativo para a de forro, tornara-se então proprietário de uma casa e de um escravo chamado Antônio, de nação Haussá. ${ }^{10}$ Naquele ano, o seu cativo estava sendo acusado de receptar parte do dinheiro roubado do coletor dos impostos dos prédios urbanos de Rio Grande na ocasião de sua mudança, o que gerou um processo-crime.

Bernardo José Soares, em 2 de outubro de 1846, fez queixa à polícia de Rio Grande. Naquela data, estava finalizando a mudança da sua residência, deixando a Rua do Rosário e passando a morar na da Caridade. Após ter se recolhido em sua nova casa:

parte da sua mobília inclusive um baú em que tinha 4:258 $\$ 401$ em onças de ouro, e patacões dentro de dois sacos pertencentes a Renda provincial da décima, e fechado 
Parentesco de nação: vestígios de uma comunidade...

as portas e janelas enquanto ia fazer conduzir o resto e acompanhar sua família, ao chegar de volta, encontrou o suplicante uma janela que bota para o pátio arrombada, e alguns vidros do caixilho quebrados, o ferrolho da fechadura d'aquele Baú em que estava o dinheiro, quebrado e este aberto e sem aquele dinheiro, e finalmente uma porta que bota para a Rua do Pito aberta por dentro [...]

Bernardo dizia estar convencido de que os responsáveis pelo furto eram o mulato Francisco, escravo de Manoel dos Santos Magano, e o preto José Mina, escravo de Joaquim José Ribeiro Guimarães. Ele os havia chamado para carregar seus trastes. Os dois foram levados à casa do subdelegado Florêncio José Cosme dos Reis. O primeiro negou tudo, enquanto o segundo teria confessado "dizendo, que aquele [o mulato Francisco] subiu pelo muro da casa, entrou nela e saiu com os dois sacos, os quais deram a um outro preto, que também se pôs em segurança". Este outro preto era Antônio, escravo de Jorge Cipriano Rodrigues Barcelos.

O africano cuja trajetória em liberdade está sendo apresentada, naquele momento, passou a não mais ser designado pelo nome do grupo africano Mina, mas a constar na documentação judiciária com as referências ao nome de seu antigo senhor, o Comendador Cipriano Rodrigues Barcelos. Sobre esta prática de os libertos incorporarem a seu nome o de seu ex-proprietário, Paulo Moreira, relativizando a idéia de que os senhores permitiam e incentivavam a seus ex-cativos a portarem seus nomes - como um sinal de poder -, afirmou:

Diversas pistas documentais apontam, porém, que os libertos manipulavam vários nomes (ou identidades). Provavelmente o sobrenome do senhor servia como uma identidade pública usada na interação destes indivíduos negros com a sociedade branca, enquanto entre os seus parceiros usavam indicativos nominais diferenciados, como referenciais étnicos, de procedência, profissional etc. (MOREIRA, 2008). 
Quer dizer, se, por um lado, era interessante ao ex-proprietário que "seus libertos" mantivessem seus nomes, por outro, os libertos tinham um interesse próprio em mantê-los, uma espécie de carta de recomendações para se mover e dialogar com a "sociedade branca".

Voltando ao caso do roubo do dinheiro dos impostos. O escravo de Jorge Antônio, de nação Haussá, foi o primeiro dos envolvidos no roubo a ser interrogado. Suas respostas às perguntas do subdelegado revelam aspectos interessantes da vida desses africanos na cidade. José Mina, aquele que confessara o roubo do dinheiro dos impostos, é chamado pelo africano haussá de José Moleque. Segundo Antônio, os dois se encontraram nas ruas da cidade, ao que José teria lhe proposto irem pegar um dinheiro que estava enterrado nas areias em frente ao beco do Louzada. Desconfiado, perguntou-lhe de onde havia roubado aquele dinheiro e José, segundo ele, afirmara que o dinheiro teria caído de um carro (uma carroça ou algo do tipo) e que o apanhara sem que ninguém o tivesse visto. Os dois foram até o local onde estava enterrado o dinheiro, e lá, José moleque entregou a Antônio haussá

uma porção de Patacões que ele respondente os recebeu em um lenço e levou dentro do tabuleiro em [que] andava vendendo quitanda, cujo dinheiro ao depois transferiu para um pequeno cofre de madeira de pinho em um balaio que levou para a Casa de seu senhor e depositou numa caixa no quarto da preta forra Rosaria dizendo a mencionada preta que a guardasse.

O detalhe quase insignificante de Antonio Haussá pegando os patacões e colocando no tabuleiro mostra como esses trabalhadores urbanos que vendiam quitanda pelas ruas, além da mobilidade, possuíam, em seus instrumentos de trabalho, recônditos onde podiam ocultar objetos e assim engrossar seus rendimentos.

Antes de analisar essa declaração do haussá Antônio, continuase com seu interrogatório ainda mais um pouco. $\mathrm{O}$ subdelegado 
Parentesco de nação: vestígios de uma comunidade...

queria saber quanto aquele recebera de dinheiro do moleque José. Antônio afirmava não ter tido tempo para contar e que era a quantia que a polícia já encontrara no sobredito balaio. Não satisfeito, o subdelegado queria saber mais. A pena do escrivão registrou, assim, o diálogo que se seguiu entre esta autoridade policial e o escravo de Jorge: perguntado "se quatorze patacões em prata e nove vinténs em cobre que lhe foram encontrados no bolso das calças na ocasião em que foi preso pertencem também aquele roubo"? Respondeu "que não pois que era dinheiro de suas quitandas".

José moleque Mina e Antônio Haussá, possivelmente, desfrutavam de liberdade de movimento pelas ruas da cidade de Rio Grande, daí se encontrarem nelas. ${ }^{11}$ Intrigante é o motivo pelo qual José chamara Antônio para lhe dar parte do dinheiro. Uma hipótese é a de que ele precisasse entregar parte do dinheiro (se não todo) ${ }^{12}$ a alguém de confiança e que não tivesse problemas em guardá-lo. Era comum que cativos entregassem quantias de dinheiro para pessoas de sua confiança guardarem. ${ }^{13}$

Ainda que a palavra moleque dê apenas uma idéia descritiva da idade de José mina, ela indica que ele devesse ser jovem. Haveria entre ele e Antônio haussá alguma deferência do primeiro com o segundo, que justificasse a entrega do dinheiro do moleque ao companheiro mais velho, o qual dizia estar em Rio Grande a "muitos anos"? O processo data de 1846, quinze anos após o fim legal do ingresso de africanos escravos no território brasileiro. José moleque (que era mina) deve ter sido um daqueles afro-ocidentais que vieram parar em Rio Grande após 1835, ano-chave da entrada de minas e nagôs no porto sulino. A conclusão a que Nina Rodrigues chegou sobre a introdução dos nagôs no Brasil pode ser aplicada aqui:

está demonstrado que dos fins do século XVIII até quase metade do século XIX, os nagôs foram largamente introduzidos no Brasil e exerceram decidida influência na constituição do nosso meio social mestiço. Pode-se afirmar com segurança, como atesta o bom estado de conservação em 
que se acham muitos [nagôs], que eles foram introduzidos não só depois dos trabalhos de limitação do tráfico ao sul da África (1817), mas ainda por muito tempo após a proibição total do tráfico (1831) (RODRIGUES 1976, p. 105).

O depoimento também revela a ocupação do escravo pertencente ao preto forro Jorge Cipriano Rodrigues Barcelos. Ao pegar os patacões desenterrados da areia, Antônio disse tê-los colocado no "taboleiro em [que] andava vendendo quitanda". Ao que parece, vender quitandas era umas das atividades mais praticadas por africanos ocidentais.

Não por acaso. Segundo Faria, apesar da atividade agrária gerar a riqueza no Brasil escravista, não era através dela que era apropriada. A apropriação da riqueza era efetuada no comércio. A autora observou que nas cidades do Rio de Janeiro e São João del Rey, as pretas minas lá residentes ou migrando para esses centros, obtiveram sucesso em acumular bens, aliando "às suas tradições culturais as inúmeras possibilidades de comércio" existentes nesses locais (FARIA, 2004, p. 209 e 237). Também na cidade do Rio de Janeiro, em análise dos presos da casa de detenção, Líbano Soares encontrou $42 \%$ de minas entre os africanos libertos com ocupação de quitandeiros (SOARES; GOMES; FARIAS, 2005, p.193).

Após o depoimento de Antônio Haussá, o subdelegado passa a questionar o moleque José. Neste momento, ele é qualificado como "preto José, de nação Usá, escravo de Joaquim José Ribeiro Guimarães" (grifos meus). José já fora chamado de mina, moleque, e agora usá, uma corruptela de Haussá, mesma nação de Antônio. Até o final do processo, ele também será chamado de nagô. Se José era mina, haussá ou nagô não se sabe dizer; no entanto, esta concorrência de nações identificando esse africano demonstra como era complexo o processo de reorganização das identidades africanas na diáspora. Serve também de alerta ao historiador para que desconfie de uma única atribuição de nação. No emaranhado e também na sobreposição desses etnômios, talvez esteja a explicação para a eficácia de termos mais 
Parentesco de nação: vestígios de uma comunidade...

genéricos, como mina e, em menor escala, nagô, para a identificação de africanos ocidentais em Rio Grande.

José contou mais alguns detalhes do roubo ao subdelegado Florêncio José Cosme dos Reis. Interessam aqui, no entanto, outras questões referentes à casa de Jorge Rodrigues Barcelos. Conforme disse Antônio, parte do dinheiro (ou todo) foi depositada em uma caixa embaixo da cama da preta forra Rosaria, que vivia em um quarto da casa de Jorge.

Rosaria Maria da Conceição e Antônio tinham uma relação mais próxima do que até então o processo dava a entender. Ao descrever como o africano haussá chegara ao quarto de Rosaria, o julgamento do escrivão emerge, revelando o preconceito por que passavam os africanos que não haviam sancionado suas relações pela Igreja: "entrou para o quarto dela respondente com quem tem amizade ilícita, e ali depositou sobre a cama uma porção de dinheiro de prata em patacões que trazia dentro de um lenço". Grifos meus.

Após o auto de perguntas de Rosaria, o proprietário da casa em que ela e Antônio viviam, e se encontravam, pede às autoridades que se proceda ao auto de busca e apreensão em sua residência "a fim de evitar qualquer extravio no caso de ser compreendido o mencionado escravo naquele roubo".

O que se vê é uma entrada virtual em dois quartos da casa de morada do preto forro Jorge Rodrigues Barcelos:

no quarto em que residia a preta forra Rosaria, que se diz ter amizade ilícita com o preto Antônio, escravo do preto forro Jorge Rodrigues Barcellos, e aí se encontrou debaixo da cama da mencionada preta Rosaria um balaio com cento e noventa e nove patacões assim mais um pequeno caixão de madeira de pinho tampado e pregado com uma pequena fenda na tampa o qual sendo aberto se encontraram cento e setenta e nove patacões que declarou a mencionada preta Rosaria pertencerem ao preto Antônio, escravo de Jorge Rodrigues Barcellos: encontrando-se mais outro caixote 
menor com oitenta patacões que declarou a mencionada preta pertencer ao preto forro de nome Rafael; e procedendo-se a busca na caixa da preta forra Maria Caetana se lhe encontraram noventa e sete patacões que declarou a mesma preta $\mathrm{M}^{\mathrm{a}}$ Caetana ser este dinheiro de sua propriedade $;^{14}$

Não foi possível saber muito mais desses pretos forros que estavam (habitavam?) no quarto de Rosaria. A única fonte que encontrou-se sobre eles foi esta. Sabe-se, pois, que possuíam somas de dinheiro guardadas e, ao contrário do que pensaram as autoridades da época, não se deve entender que todo o pecúlio que tinham cuidadosamente depositado em caixas fosse de origem ilegal, fruto do roubo aos impostos dos prédios urbanos da Cidade. É bastante possível que, se não todo, pelo menos uma parte, fosse produto do trabalho deles.

O outro quarto guardou-nos uma melhor sorte:

passando-se a proceder a busca no quarto do preto forro Belchior declarou ele ter enterrado dentro de uma panela de barro junto à sua cama uma porção de dinheiro e desenterrada a dita panela se encontrou a quantia de quatrocentos e cinco patacões, que declarou pertencer ao preto forro Fabrício Magalhães cento e vinte e cinco patacões, à preta forra Carlota da Silva Rios, sessenta e cinco patacões, e quarenta e cinco patacões que fazem o completo d'aquela quantia disse serem de sua propriedade cujo dinheiro todo reunido fazia a soma e quantia de um conto novecentos e vinte mil réis que no mesmo ato mandou o Subdelegado que fosse depositado esta quantia em mãos de Antônio José Ribeiro Guimarães que presente se achava.

Todos os pretos forros encontrados no quarto de Belchior tiveram suas alforrias encontradas nos livros notariais de Rio Grande e eram todos de nações da África ocidental. 
Parentesco de nação: vestígios de uma comunidade...

Como se vê no trecho do documento acima citado, todo o dinheiro possuído por esses pretos forros e pelo cativo Antônio haussá, foi entregue a um depositário e posteriormente apreendido com a finalidade de ser devolvido ao queixoso Bernardo Soares. Caso os patacões que esses pretos forros guardavam em caixas e panelas não fossem originários do roubo - como considera-se -, a polícia executou uma ação terrível, cobrindo parte do rombo deixado pelo furto com as economias desses africanos, reunidas certamente com grande esforço e trabalho.

Por outro lado, a descrição da casa do mina Jorge Barcelos permite algumas considerações sobre quais eram os critérios utilizados por africanos ocidentais na seleção dos parceiros de moradia, indicando que esses eram preferencialmente escolhidos entre aqueles da mesma nação, ou com algum parentesco étnico. Isto se confirma pelo fato de que em um dos quartos da casa residirem, ou estarem alocados, apenas africanos ocidentais. O critério do outro quarto infelizmente é uma incógnita, pois não foram encontradas outras referências da origem de seus freqüentadores.

O parentesco étnico foi uma das estratégias adotadas pelos africanos para reconstruírem no Novo Mundo laços que substituíssem a rede de amparo usufruída por esses homens e mulheres nas extensas linhagens de que faziam parte no seio de suas sociedades no continente africano ${ }^{15}$. Laços rompidos com violência na África foram recompostos em Rio Grande, na forma de uma família simbólica que se tornaria canal privilegiado da solidariedade africana. Sobre essa questão, Reis (2003, p. 415) afirmou que "a palavra parente foi escolhida do vocabulário da língua do senhor para significar patrício. Os membros de um mesmo grupo étnico eram 'parentes' entre si." Grifos do autor.

De volta à vida do mina Jorge. Antônio haussá, seu escravo, acabou por ser condenado e, conseqüentemente, Jorge também. Este preto forro, de acordo com a pena decidida pelo Juiz, teria de pagar o valor de setecentos e trinta e oito mil, quinhentos e setenta e três réis, referente aos juros, multa dos valores furtados, bem como 
das custas do processo. No entanto, como esse valor ultrapassava os seiscentos e cinqüenta mil réis pelos quais fora avaliado o haussá Antônio, Jorge Barcelos o cedeu para o queixoso Bernardo José Soares. Joaquim José Ribeiro Guimarães fez o mesmo em relação a José moleque, o qual, segundo ele, era de nação nagô. Francisco mulato, o outro cativo envolvido no caso, veio a falecer enquanto se desenrolavam os trâmites jurídicos do processo. O processo envolvia outras pessoas, de condição livre e de nacionalidade portuguesa, que não tiveram seus envolvimentos no crime tratado aqui. ${ }^{16}$ O destaque que se dá a este caso se deve primordialmente à entrada efetuada na casa do africano Jorge, personagem destacado da história dos minas e nagôs de Rio Grande.

Esse processo correu durante os anos de 1846 e 1848, nos bancos dos tribunais rio-grandinos. Passados nove anos, uma outra aparição de Jorge entre africanos ocidentais foi documentada. Desta vez, ele figura como testemunha em um testamento nuncupativo - documento judicial ditado oralmente. A testadora era Maria do Bonfim da Silva, a qual, antes de falecer, em 1857, declarou, na presença de Jorge Barcelos e outros africanos, sua intenção de alforriar uma jovem escrava crioula, filha de uma africana também cativa sua. Boa parte das testemunhas, assim como os que ocupavam a casa de Jorge, eram africanos ocidentais.

Jorge Barcelos, testemunha dos derradeiros momentos de vida de Maria do Bonfim, quando perguntado sobre o conteúdo da declaração desta, afirmou frente ao escrivão da Provedoria de Rio Grande que:

achando-se ele testemunha em casa de morada do preto forro Victor Antônio de Vasconcellos, aonde se achava doente de cama a preta forra Maria do Bonfim da Silva, mas em seu perfeito juízo e claro entendimento, por esta foi dito a ele testemunha e aos pretos Maximiano da Silva Rios, Felícia Maria da Conceição. Igídio José da Silva, e Antônio de Miranda, e a mais algumas pessoas, que também 
Parentesco de nação: vestígios de uma comunidade...

ali se achavam, que era sua última vontade forrar como com efeito forrava, a sua crioulinha Damiana de quatro anos de idade filha da preta Justina, que foi sua escrava, e que isto sucedeu no dia 22 de Maio do corrente ano [1857] [...] e que mesmo antes disso e por vezes ouviu dizer a mesma preta Maria, que estava criando aquela Crioulinha Damiana como sua filha, e que havia de forrá-la. ${ }^{17}$

Recuando no tempo, é importante saber que Maria era viúva de um africano liberto de nação mina, cujo nome era Joaquim de Antiqueira, falecido em 1853. Pela presença dessas pessoas no momento da morte de sua mulher e herdeira, é possível que Antiqueira tivesse relações pessoais com esses africanos quando vivo. ${ }^{18} \mathrm{O}$ testamento de Maria do Bonfim aponta para a possibilidade de os africanos ocidentais estarem inseridos em redes de sociabilidade e solidariedade nada desprezíveis. Das testemunhas arroladas em seu testamento, todas eram africanas, e pelo menos três eram de grupos da África Ocidental.

Jorge Cipriano Barcellos preto forro, idade 60 anos, de Nação Nagoa, proprietário, morador nesta Cidade, solteiro.

$2^{\mathrm{a}}$ testemunha

Felícia Maria da Conceição preta forra, idade 40 anos, natural da Costa da África, moradora nesta Cidade aonde vive de quitandas, casada.

$3^{\text {a Testemunha }}$

Maximiano da Silva Rios idade de 40 anos pouco mais ou menos, natural da Costa da África, preto forro, oficial de pedreiro e morador nesta Cidade, solteiro.

$4^{\mathrm{a}}$ Testemunha

Antônio de Miranda, preto liberto, natural da Costa da Mina, idade 34 anos, solteiro, morador nesta Cidade onde vive de suas quitandas. 


\section{$5^{\text {a Testemunha }}$}

Igídio José da Silva, preto forro, idade 62 anos, natural da Costa da África, solteiro, vive de seus negócios de quitanda e morador nesta Cidade.

Ao cruzar o nome dos pretos forros que foram testemunhas das declarações de Maria do Bonfim com as alforrias registradas nos tabelionatos de Rio Grande, verificou-se que Maximiano da Silva Rios, descrito somente como "natural da Costa da África" no testamento, em sua alforria, era designado como nagô. Em primeiro de setembro de 1846, Antônio da Silva Rios concedeu alforria, a Maximiano, preto de nação nagô, oficial de pedreiro, após este the pagar a alta quantia de um conto e quinhentos mil réis. ${ }^{19}$

O Maximiano do testamento de Maria do Bonfim era, sem dúvida, o mesmo que se alforriara onze anos antes. Incorporara o sobrenome de seu antigo proprietário e preservara sua ocupação de oficial de pedreiro. A mesma certeza não foi possível obter com a testemunha Felícia Maria da Conceição. Em vinte e sete de agosto de 1841, uma preta mina, também chamada Felícia, juntamente com seu filho Miguel, nascido no Brasil, alforriou-se ao pagar a quantia de um conto de réis por ambos a seu então proprietário Jacinto de Souza Nunes. ${ }^{20}$ Ela poderia ser a mesma que ouviu a companheira de Joaquim de Antiqueira alforriar verbalmente Damiana, mas também poderia ser uma outra mulher. Mas que incrível coincidência a única Felícia com alforria registrada em tabelionatos de Rio Grande também ser uma mina.

Não foram localizadas as alforrias das demais testemunhas Igídio José da Silva e Antônio de Miranda. O que o testamento de Maria do Bonfim revela, de novidade, é que o africano Jorge Barcelos poderia ser considerado nagô, grafado no original Nagoa. Daí chamá-lo de um personagem de identidade mina-nagô, ele mesmo trazia essa relação, ora sendo caracterizado como mina em um documento, ora como nagô em outro. 
Parentesco de nação: vestígios de uma comunidade...

Um outro caso semelhante, não envolvendo Jorge, fornece mais algumas perspectivas da reorganização da comunidade africana ocidental em Rio Grande. A fonte mais uma vez utilizada foi um testamento nuncupativo de um africano de nação Mina, o preto forro Manoel Francisco Bento.

O segundo caso desse tipo de fonte refere-se a um fato ocorrido em 1860. Naquele ano, Manoel Francisco Bento, com setenta anos, preto forro de nação mina, casado com a preta forra Helena Maria Anselmo, de cinqüenta anos, faleceu de tubérculos pulmonares. Horas antes de sua morte - às três horas da manhã - se encontravam em sua casa, pelo menos, as seis testemunhas para as quais relatou os seus últimos desejos. ${ }^{21}$ Três dessas eram "naturais da Costa da Mina" ou "de nação Mina". Eram relativamente jovens, com idade entre 30 e 35 anos. Com ocupações de cangueiro, carpinteiro e sapateiro. Um era afilhado de batismo do casal, outro era sobrinho de Helena. Outras duas testemunhas eram de nação Nagô (Nagó e Nagoa no original), um vivia de suas quitandas no mercado, outro era "trabalhador". Um preto forro Crioulo também testemunhou o ocorrido, ele era carpinteiro e também vivia de negócios. ${ }^{22}$

$1^{\text {a }}$ Testemunha

João Rocha Mina de Nação, idade 30 anos, morador nesta Cidade, vive de seu trabalho de Cangueiro, solteiro.

$2^{\text {a Testemunha }}$

Francisco José Pereira, preto forro natural da Costa da Mina, idade, 35 anos, vive de ser carpinteiro, morador nesta cidade.

$3^{\text {a }}$ Testemunha

Joaquim Antônio de Almeida, preto forro, natural da Costa da Mina, idade 30 anos, solteiro, sapateiro, morador nesta Cidade. 
$4^{\text {a }}$ Testemunha

Augusto João Barcellos, preto forro de Nação Nagoa, idade 45 anos, vive de suas quitandas no mercado.

$5^{\text {a Testemunha }}$

Adriano Francisco Ramalho, preto forro Natural da Costa da África Nagó, idade 30 anos, trabalhador nesta Cidade.

$6^{\text {a Testemunha }}$

Manoel da Silva Santos, natural desta Cidade, idade 35 anos, casado, vive de seu ofício de carpinteiro, e de andar embargado em seus negócios.

A primeira testemunha, João Rocha, afirmou ser afilhado de batismo do falecido preto Manoel Francisco Bento e de sua mulher. E confirmava que, antes de morrer, seu padrinho havia declarado que deixava tudo para sua madrinha Helena. A mulher do falecido é a única pessoa dos listados nesse documento que não tem sua origem determinada explicitamente. Tudo indica que ela fosse uma mina. Mas, sobretudo, o que reforça essa possibilidade é o fato de o mina Francisco José Pereira, o segundo a testemunhar, afirmar que a mesma era sua Tia. ${ }^{23}$

Além da força do parentesco étnico entre esses africanos, como fica evidente tanto no testamento de Maria do Bonfim como no de Manoel Francisco Bento, há mais dois elementos novos neste último. João da Rocha, ao declarar ser afilhado do casal, indica que os africanos traficados para Rio Grande antes de 1850 poderiam receber os "santos óleos" de pessoas com alguma proximidade cultural, as quais teriam a responsabilidade de instruí-los na nova vida em cativeiro, mas também de auxiliá-los a recompor as suas vidas no Novo Mundo.

Mortari, ao analisar os laços de compadrio entre africanos na Desterro da primeira metade do XIX, observou que os adultos africanos, ao serem batizados, provavelmente, tinham a escolha dos seus padrinhos efetuada pelo seu proprietário, em razão de 
Parentesco de nação: vestígios de uma comunidade...

esses recém-chegados dificilmente terem relações afetivas que os esperassem. Contudo, ao contrário do que poderia se supor, esse sacramento não se tornou somente uma formalidade. A autora considera que com o tempo os africanos souberam aproveitar o que inicialmente lhes fora imposto, fazendo com que os vínculos de apadrinhamento fossem por eles "utilizados para criar possibilidades de ajuda e auxílio mútuos" (Mortari, 2007, p. 153).

Os dados que encontrou demonstram que os africanos adultos tinham, com freqüência, como padrinhos pessoas com a experiência passada ou presente da escravidão, ou seja, libertos e escravos. Além da marcante experiência do cativeiro, padrinhos e afilhados tinham práticas de trabalho e também alguns referenciais culturais em comum. Mortari (2007, p.155-156) encontrou casos em que os padrinhos de africanos adultos eram os mesmos que batizavam as crianças. Isto quer dizer que o proprietário, por vezes, avalizava as escolhas da própria comunidade cativa e, portanto, os padrinhos não eram escolhidos à revelia desta.

Pode-se conjeturar que a relação de compadrio observada no testamento de Manoel Francisco Bento tenha sido uma escolha fundamentada no parentesco de nação entre ele e João Rocha. A julgar pela idade que este último tinha em 1862, cerca de trinta anos, este mina veio para o Brasil bastante novo e foi batizado pelo já experiente mina Manoel Francisco. O compadrio deve ter reforçado o parentesco étnico existente entre esses dois africanos de nação mina, embora o contrário também possa ser dito, que seus laços de nação foram fortalecidos com o apadrinhamento de João por Manoel.

A outra relação explicitada pelo testamento é um caso mais raro, trata-se da possível consangüinidade entre tia e sobrinho. Este caso gera muitas dúvidas. Seria o africano Francisco José Pereira de fato sobrinho de Helena, mulher de Manoel, ou ele a chamava dessa forma a partir de outra lógica que não a da consangüinidade? Poderia ser com base em uma relação ritual, por exemplo. Por outro lado é possível que africanos encontrassem familiares no Novo 
Mundo, principalmente em cidades. ${ }^{24}$ A cidade portuária de Rio Grande era, sem dúvida, local privilegiado para encontrar parentes, afinal, era por onde boa parte dos escravos novos chegava na província. Claro que essa era uma possibilidade restrita, contudo, ainda assim, era uma possibilidade real.

Independente se Helena e Francisco fossem ou não parentes de sangue, as informações reunidas até aqui permitem supor, como fez João Reis (2003, p. 415), para a Bahia, que, no Rio Grande, "a nação étnica ganhou feições de uma grande família e a identidade em torno dela talvez fosse o principal mecanismo de solidariedade e organização das vidas da maioria dos africanos". Talvez a existência do parentesco de sangue não alterasse significativamente a importância do congênere de nação entre os africanos de Rio Grande. ${ }^{25}$

Até agora, este artigo "adentrou" no interior de três casas de pretos forros. Na do personagem principal Jorge Cipriano Rodrigues Barcelos, por ocasião da busca e apreensão efetuada pela polícia. Na de Victor Antônio de Vasconcellos, por ocasião do testamento de Maria do Bonfim, no qual Jorge, junto a outros africanos, fora testemunha; e, finalmente, na residência de Manoel Francisco Bento, também por ocasião de seu testamento.

$\mathrm{Na}$ casa de Jorge, viviam ou se encontravam oito pessoas, das quais cinco eram confirmadamente africanas ocidentais, de nações haussá, mina e nagô. Nas últimas horas de vida de Maria do Bonfim, passadas na casa do preto forro Victor Antônio de Vasconcelos, fora o dono da casa e mais algumas pessoas, que também ali se achavam ${ }^{26}$, estavam presentes cinco testemunhas, todas africanas e pelo menos três ocidentais, de nações nagô e mina, entre elas Jorge. $\mathrm{Na}$ moradia de Manoel Francisco Bento, além de sua mulher Helena, seis pessoas compartilharam seus últimos momentos e ouviram seu derradeiro desejo, dessas, apenas um era crioulo, os demais eram africanos ocidentais: minas e nagôs.

Nas três casas, dos 22 adultos presentes que foram nomeados na documentação, seguramente dezesseis eram africanos, e desses, quatorze eram de nações procedentes da África ocidental, os dois 
Parentesco de nação: vestígios de uma comunidade...

restantes foram apenas chamados de "africanos". Dos seis restantes, apenas um, com certeza, era crioulo, os demais não tiveram origem descrita; no entanto, certamente tinham fortes ligações com os africanos. Maria do Bonfim era casada com um (Joaquim de Antiqueira). Victor Vasconcellos, além de abrigá-la em sua casa nos seus últimos momentos, aparece em uma alforria passada por Jorge Barcelos assinando por ele. Dos três ocupantes sem origem determinada da casa de Jorge, um deles, Rosaria Maria da Conceição, tinha "amizade ilícita" com o haussá Antônio. Quer dizer, se fossem homens e mulheres nascidos no Brasil, conviviam estreitamente com africanos ocidentais.

A partir desses vestígios documentais das experiências de moradia e de proximidade no momento da morte, é possível afirmar - parafraseando Oliveira (1995/96) - que os africanos ocidentais de Rio Grande preferiam viver e morrer no meio dos seus. O que demonstra que eles formaram uma rede comunitária pragmática, dentro das possibilidades sociais que lhes foram apresentadas, baseadas no parentesco simbólico de nação e na experiência comum da escravidão, reforçada pelo compadrio e sem desprezar relações consangüíneas.

As pesquisas de Oliveira (1995/96) e Reis (2003) para a Salvador oitocentista demonstram que os arranjos das residências de africanos eram definidos com freqüência por critérios de pertencimento a uma determinada identidade étnica. Era incomum haver escolhas de companheiros de morada entre indivíduos de grupos da África central-atlântica (bantos: Angolas, Congos, Cabindas, Benguelas) e africanos ocidentais (sudaneses: Minas, Nagôs, Haussás, Jejes), mas havia convívio entre si de grupos dessas grandes regiões como observado entre os ocidentais de Rio Grande acima mencionados.

Isso não significa que uma pessoa identificada como Mina não pudesse morar ou casar com uma Benguela ou Angola, mas que esse tipo de arranjo provavelmente era mais difícil de acontecer, porque necessitaria de que ambos abrissem mão de elementos importantes constitutivos de suas identidades. ${ }^{27}$ Em outras palavras, era 
mais fácil a um nagô se aproximar de um mina do que de um angola. Assim como para um benguela era mais complicado estreitar relações com um haussá do que com um cabinda. A realidade concreta, entretanto, demonstra que essas relações ocorriam. Haja vista, por exemplo, o casal estudado por Moreira (2008), formado por Joana Guedes e Marcelo, ela mina e ele angola. Todavia, essa devia ser uma exceção e não a regra.

Aspecto importante presente na documentação das três casas de forros de Rio Grande são as ocupações das pessoas que habitavam ou transitavam por essas moradas. Elas revelam que boa parte desses africanos ocidentais trabalhava com quitandas, no pequeno comércio ambulante de alimentos, perambulando com seus tabuleiros pelas ruas desta cidade portuária. Uma outra parte considerável deles desempenhava ofícios do tipo carpinteiro, pedreiro, cangueiro e sapateiro.

Claro que a documentação abrange uma parcela modesta da população total de africanos libertos de Rio Grande, por isso não oferece grande peso estatístico. Contudo, ela sugere que minas e nagôs, em particular, e os africanos ocidentais, em geral, buscavam (e, de algum modo que não está claro, conseguiam) se ocupar em trabalhos que lhes garantiam bons rendimentos pecuniários, desempenhados preferencialmente no ambiente urbano da cidade de Rio Grande. Há que se ter em mente que isso não era uma regra observável para todos os africanos ocidentais, principalmente quando observados os que viviam sob o cativeiro. Basta olhar algumas listas de escravos em inventários para notar que os minas e nagôs eram empregados também nos mais diversos trabalhos. ${ }^{28}$

Pesquisas sobre a cidade do Rio de Janeiro vêm demonstrando que os minas se organizaram etnicamente em torno das ocupações urbanas ao ganho, chegando a ser hegemônicos entre as quitandeiras e os carregadores de café. Sugere-se que, por dominarem esses ramos do mercado de trabalho, eles retinham na sua comunidade étnica, o pecúlio necessário para que tivessem acesso ao mercado da liberdade. ${ }^{29}$ 
Parentesco de nação: vestígios de uma comunidade...

Essas interpretações são válidas para explicar os altos patamares de alforrias conquistadas por ocidentais em Rio Grande, cerca do dobro da sua participação na população escrava africana. Também é significativo para esta questão pensar o papel da sociabilidade desses africanos na conquista da liberdade.

O caso de Jorge aponta para a importância das casas de libertos na recomposição daquela comunidade africana e dos critérios étnicos nos arranjos de moradia observados nesses espaços. Explicome. A geração de africanos minas e nagôs que conseguiu se alforriar e constituir pecúlio suficiente para tornar-se proprietária de casas, ao propiciar esse espaço para outros libertos e também para escravos, criou o ambiente para facilitar trocas culturais entre esses homens e mulheres, além de possibilitar a eles um espaço onde praticar cultos africanos menos expostos aos olhos repressivos de então.

Mas não só isso. Essas casas propiciavam a libertos mais pobres e a cativos um lugar relativamente a salvo do arbítrio de senhores, ex-senhores e da polícia. Apesar de não se poder esquecer que a casa de Jorge foi vasculhada pela polícia a seu pedido.

O caso do roubo dos impostos dos prédios urbanos de Rio Grande indica que essas casas poderiam ser receptoras de ações ilegais, especialmente de libertos e cativos africanos. Numa comunidade onde a busca incessante e freqüente pela alforria, confirmada pelos altos números em que minas e nagôs a conquistavam, o furto podia ser uma das ações empreendidas com a finalidade de investir na aquisição da liberdade. Este tipo de contravenção pode ser compreendido dentro de uma perspectiva de "economia interna dos escravos", termo criado pela historiografia norte-americana que "abrange todas as atividades desenvolvidas pelos cativos para aumentarem seus recursos, desde o cultivo de suas roças à caça e, inclusive, ao furto" (SLENES, 1999, p. 198). Segundo este autor, como as lutas entre senhores e escravos ocorreram em diversos contextos, a economia escrava adquiriu diferentes formas de acordo com suas possibilidades. (Grifos meus.) 
Em outras palavras, pensando no caso dos impostos dos prédios, é possível que as possibilidades de angariar pecúlio para a aquisição da liberdade por Antônio haussá, cativo de Jorge, fosse diferente das de outros minas, e o contexto que se apresentou a ele era por demais convidativo: uma boa porção de patacões sem precisar nada além de levá-los no seu chapéu para a casa de seu senhor, onde aparentemente habitava. Era a sua forma de juntar algum pecúlio a mais às suas economias e, no futuro, quem sabe, comprar a sua liberdade. O roubo de dinheiro em moeda para a aquisição da liberdade parece ter sido uma prática recorrente entre os escravos. Se não era muito praticado, ao menos a possibilidade era assumida pelas autoridades. ${ }^{30}$

A compra da liberdade seria o provável motivo para o furto aos impostos dos prédios urbanos de Rio Grande. Talvez o parentesco étnico entre José moleque, que podia ser haussá, mas também mina ou nagô, com Antônio haussá, escravo de Jorge Barcelos, justificasse a confiança depositada nele pelo jovem africano ao the entregar o dinheiro furtado, que poderia ter acabado nas mãos de algum senhor como pagamento pela liberdade de um parente, não fosse a ação da polícia.

O certo é que os laços étnicos entre africanos ocidentais, minas e nagôs e, em menor escala, haussás e jejes, foi o cimento que consolidou a gama de relações comunitárias desenvolvidas por eles em Rio Grande. Essa reorganização comunitária propiciou o acesso privilegiado desses africanos às alforrias pagas, com a entrega de valores pecuniários aos proprietários.

Com efeito, os africanos ocidentais pagavam pela grande maioria de suas alforrias (Tabela 3). As mulheres, $76,84 \%$ e os homens, $81,81 \%$ das que lhes eram entregues. Ao serem comparados aos africanos da área Central-atlântica do continente, fica evidente como a reorganização dos grupos étnicos era fundamental no "mercado da liberdade". Enquanto mulheres e homens da África Ocidental chegavam a patamares muito altos de pagamento pela 
liberdade, eles e elas da região Central-atlântica chegavam, respectivamente, a comprar 34,48\% e 53,25\% das alforrias que lhes eram entregues. ${ }^{31}$ Isto significa que os provenientes da área central-atlântica alforriavam-se segundo um padrão semelhante ao dos crioulos. ${ }^{32}$

\section{Tabela 3 - Região da África e sexo dos libertos pelos tipos de alforria}

\begin{tabular}{l|c|c|c|c|c|c|c|c|}
\multirow{2}{*}{ Tipos } & \multicolumn{4}{|c|}{ África Central Atlântica } & \multicolumn{4}{c|}{ África Ocidental } \\
\cline { 2 - 10 } & \multicolumn{3}{|c|}{$\mathrm{H}$} & \multicolumn{2}{|c|}{$\mathrm{M}$} & \multicolumn{2}{|c|}{$\mathrm{H}$} & \multicolumn{2}{c|}{$\mathrm{M}$} \\
\cline { 2 - 9 } & $\mathrm{n}^{\circ}$ & $\%$ & $\mathrm{n}^{\circ}$ & $\%$ & $\mathrm{n}^{\circ}$ & $\%$ & $\mathrm{n}^{\circ}$ & $\%$ \\
\hline Paga & 20 & 34,48 & 41 & 46,03 & 72 & 81,81 & 73 & 76,84 \\
\hline Condicional & 21 & 36,21 & 12 & 19,05 & 3 & 3,41 & 5 & 5,26 \\
\hline $\begin{array}{l}\text { Sem obrigação ou } \\
\text { condição }\end{array}$ & 16 & 27,59 & 23 & 34,92 & 13 & 14,77 & 17 & 17,9 \\
\hline Desconhecida & 1 & 1,72 & 1 & 0 & 0 & 0 & 0 & 0 \\
\hline Subtotal & 58 & 100 & 77 & 100 & 88 & 100 & 95 & 100 \\
\hline Total & \multicolumn{3}{|c|}{135} \\
\hline
\end{tabular}

Fonte: APERS, Livros Notariais de Rio Grande 1812-1865

Se o maior número de africanos entre os alforriados era decorrente do pagamento pela carta de liberdade, aqueles provenientes da África Ocidental foram os principais protagonistas dessa diferença. Em outras palavras, o predomínio dos africanos sobre os crioulos na conquista da liberdade ocorreu devido à agência dos minas e nagôs no pagamento de suas manumissões.

O número elevado de alforrias pagas em mãos de africanos ocidentais no século XIX é observável nas cidades onde eles estiveram presentes em números consideráveis e puderam constituir uma comunidade étnica sob comando da nação mina. Esta é uma afirmação que encontra ressonância para o Rio de Janeiro, mas também para importantes cidades da província sulina, como Porto Alegre e provavelmente Pelotas.

Para a capital do Império, os estudos disponíveis demonstram que os africanos ocidentais, a maioria conhecida como minas, constituíam-se num grupo de comportamento diferenciado entre os africanos. Ocupavam-se numerosamente em serviços ao ganho e também 
teriam uma maior eficiência na organização de instituições como irmandades, cantos e juntas de alforrias, o que lhes proporcionaria uma eficiência em arrecadar recursos para a compra da liberdade. ${ }^{33}$ Estabeleciam espaços de convivência e ocupavam papel de liderança nas casas de zungú - casas em que geralmente se servia angu, mas também era local para cultos e práticas de costumes africanos, assim como esconderijo para cativos em fuga (SOARES, 1998).

Em Porto Alegre, os dados disponíveis são relativos aos alforriados da segunda metade do XIX. Os africanos ocidentais constituíam 33\% daqueles vindos da África que alcançaram carta de liberdade. Das alforrias destinadas aos minas, 65\% eram compradas, enquanto os nagôs pagavam por $80 \%$ das suas (MOREIRA, 2008). Muitas dessas cartas eram produto do "esforço coletivo dos parentes", e demonstravam a competência deste grupo para se libertar (MOREIRA, 2007, p. 17). Em Pelotas, nos registros de alforrias passadas a africanos entre 1832 a 1849, minas e nagôs juntos constituíam 41,5\% deles (REIAS; GOMES; CARVALHO, 2004).

Foi esse poder de reorganização dos ocidentais que talvez estivesse presente como lógica das alforrias passadas pelo personagem deste artigo, Jorge Cipriano Rodrigues Barcelos. Os cativos alforriados por ele pagaram pelas suas cartas, alguns claramente com auxílio de terceiros.

Em 1853, aos vinte e cinco dias de junho, o nagô de quarenta anos Luiz, pagou oitocentos mil réis a Jorge, o qual afirmava concedêla a ele não só pelo dinheiro que lhe fora entregue, mas também pelos bons serviços prestados. ${ }^{34}$

Em 1871, foi a vez de Tereza, uma mina solteira e sem filhos, de quarenta anos. ${ }^{35}$ Ela lhe pagou um conto de réis pela sua liberdade. Jorge pediu a Victor Antônio de Vasconcellos que assinasse a carta por ele, pois não sabia ler nem escrever. Victor era o preto forro proprietário da casa na qual Maria do Bonfim viera a falecer e expressar sua última vontade na presença de Jorge. É possível 
Parentesco de nação: vestígios de uma comunidade...

que Victor fosse um crioulo com trânsito pela comunidade minanagô, ou um africano que aprendera a escrever (ou assinar) na língua dos portugueses. Independentemente disso, certamente Victor e Jorge eram velhos conhecidos.

Dois anos depois, em 1873, na cidade vizinha de Pelotas, o preto forro Jorge alforriou o cangueiro "de todo o serviço” Rufino, um africano solteiro de quarenta anos de idade. Infelizmente o registro da carta dele não especifica sua origem. O pagamento dos setecentos mil réis da liberdade deste cangueiro foi efetuado por um preto forro chamado Luiz França Mascarenhas

do modo seguinte, a saber, quatrocentos mil réis moeda corrente em dinheiro, uma letra de trezentos e nove mil réis moeda corrente, que se vence no prazo de três meses contados desta data inclusive o prêmio de um por cento ao mês, ficando o preto Rufino obrigado a assinar o contrato que se obrigou a fazer com o preto forro Luiz da França Mascarenhas para lhe adiantar o dinheiro que me entrega para a sua liberdade. ${ }^{36}$

A alforria foi passada em Pelotas não por Jorge em pessoa, mas por seu procurador Prudêncio José da Silva. O preto forro Luiz Mascarenhas, que aparece pagando pela liberdade de Rufino, conforme a sua provável alforria, seria mina. ${ }^{37}$

A última alforria passada por Jorge data de 1878. Foi para a "africana" Generosa, que tinha cinqüenta anos e não possuía filhos. Registrada em Rio Grande, a carta de liberdade dessa mulher lhe foi conferida pelo preço de quatrocentos e cinqüenta mil reis, no dia dezenove de outubro daquele ano. ${ }^{38}$ Desta vez, Jorge pediu a um homem chamado Pedro José Duarte para escrever e assinar o documento no qual transferia para Generosa a propriedade que tinha sobre ela. 


\section{O derradeiro documento de Jorge}

Aos vinte e um dias do mês de Agosto de 1879, foi aberto o Testamento de Jorge Cipriano Rodrigues Barcelos. O africano que teve momentos singulares de sua vida observados neste estudo já não vivia mais. Havia ditado suas últimas determinações à sua companheira Mariana Monteverde, sua herdeira e mulher.

\section{Em Nome de Deus Amém}

Eu Jorge Cypriano Rodrigues Barcellos, preto forro, tenho resolvido fazer o meu testamento pela maneira seguinte.

Sou Natural da Costa d' África, e sou maior de setenta anos, sou casado com a preta forra Mariana Monteverde, de cujo matrimônio não tenho filhos.

Instituo minha universal herdeira à minha dita mulher Mariana Monte Verde, que será também minha primeira testamenteira. O que me devem e o que eu devo, minha mulher tem de tudo conhecimento, e fará as cobranças e pagamentos como for de direito.

Nomeio meu segundo testamenteiro o preto forro, José Simão, alfaiate, e terceiro o preto forro Marcolino José Pinto.

Pelo presente fica revogado, e sem vigor algum outro qualquer testamento ou codicílio de anterior data.

E desta forma tenho feito o meu testamento que quero se cumpra como nele se constava e declarava, e vai por mim ditado e escrito e assinado a meu rogo por eu não saber ler nem escrever, por Fernando Affonso de Freitas Noronha. Rio Grande, 24 de Outubro de 1878. ${ }^{39}$ 
Parentesco de nação: vestígios de uma comunidade...

Sua mulher, Mariana Monteverde, era africana "da Costa", alforriada em 1842, por Francisco de Paula Monteverde. Na cidade de Rio Grande, ela pagou a esse homem a quantia de oitocentos mil réis por sua liberdade, no dia quinze de janeiro daquele ano. ${ }^{40}$ Mariana aparece envolvida com uma outra alforria, registrada em Pelotas, colaborando para a liberdade de uma provável parenta de nação. Em 1849, a preta mina Maria Luiza recebeu sua carta de Guiomar Martins da Silveira

em razão aos muitos bons serviços que me tem prestado [...] visto que em atenção as minhas circunstâncias ela há dado em troco uma outra escrava de nome Mônica de Nação Mina que para esse fim comprara a preta forra Mariana Francisca de Paula Monte Verde. ${ }^{41}$

É bem verdade que ajudava uma mina entregando outra. Este ato, como a documentação em geral, revela uma complexidade muito grande das questões étnicas, demonstrando que não é possível fazer generalizações sem cuidado. Isto significa que, na matemática da solidariedade de nação, o componente étnico era importante, mas junto a outros elementos. Precisam ser considerados o tempo em que os africanos estavam na cidade, suas possibilidades de estabelecer relações pessoais e parentais simbólicas, mas também a ocupação, o gênero e a idade; enfim, são numerosas as variáveis que poderiam atravessar o parentesco de nação. Além do que, no caso da alforria desta mina - Maria Luiza - que teve a colaboração da viúva de Jorge, deve ser colocado em pauta a oferta de cativos à venda, bem como uma possível interferência da senhora da alforriada, que poderia querer uma "peça" equivalente - também mina - para substituir a que se tornaria liberta. Mariana pode não ter tido muitas opções, nem intenções, de não comprar uma mina para substituir a outra.

Voltando ao testamento de Jorge Barcelos. Nele, Jorge é identificado como natural da Costa da África. É difícil estabelecer o 
quanto essa classificação era proveniente dele e quanto era do escrivão a quem ditava seu testamento. No entanto, ela sinaliza para o fato de que, passados praticamente trinta anos da proibição do tráfico transatlântico de escravos, a população africana de Rio Grande já não deveria ser tão numerosa como outrora. Assim, as diferenças de nação aos poucos devem ter sido apagadas, ou dissipadas, frente à escassez de africanos na população, os quais cada vez mais deviam ser vistos pelos olhos alheios como um grupo homogêneo, praticantes de costumes bárbaros que deviam ser combatidos. Talvez, nesse contexto, Jorge tenha se tornado mais africano do que mina, possibilitando uma rede maior de alianças com conterrâneos, agora não só da Costa da Mina, mas da Costa da África.

Nation Kinship: vestiges of an African community in Rio Grande

Abstract. This work investigates the experiences of searching for freedom undertaken by freed and slaves in the county of Rio Grande, in the extreme south of the Brazilian Empire during the nineteenth century. Unlike observed in other regions of Brazil, in Rio Grande those born in Africa were more successful than those born in Brazil to get free from slavery. In establishing this framework it was a key action of the West African community. Minas and nagôs were substantial part of the African population of the port city. They reorganized their lives around the nation kinship, reaching the hegemony of the free market among Africans, through the purchase of their manumissions.

Keywords: Freedom. African Community. West African.
Abreviaturas
APERS - Arquivo Público do Estado do Rio Grande do Sul
VFSP - Vara de Família Sucessão e Provedoria
RG - Rio Grande 
Parentesco de nação: vestígios de uma comunidade...

\section{Notas}

${ }^{1}$ Exemplos bem sucedidos dessas abordagens no sul do Império já podem ser listados: Oliveira (2006), Reis; Gomes; Carvalho (2004), Moreira (2008) e Mortari (2007).

${ }^{2}$ As alforrias analisadas neste estudo são provenientes de registros notariais e de testamentos, aquelas são chamadas de alforrias notariais enquanto essas de alforrias testamentárias.

${ }^{3}$ Estes dados podem ser vistos em uma análise mais detalhada em Scherer (2008), especialmente nos capítulos 3 e 4 .

${ }^{4} \mathrm{O}$ modelo de classificação das alforrias por mim adotado é aquele construído por Paulo Moreira nos seus trabalhos sobre a temática em Porto Alegre. Divide-se em três grupos: as pagas, as condicionais e as sem ônus ou condição. Alforrias pagas são consideradas aquelas em que havia entrega de dinheiro, mercadoria ou outro escravo em troca da carta. As condicionais eram cartas em que os cativos recebiam a liberdade desde que cumprindo com condições das mais diversas. No caso de o cativo pagar por suas alforria e mesmo assim receber condições para obtê-la, a carta é classificada como paga. As sem ônus ou condição são aquelas em que o senhor atestava a gratuidade da alforria ou indicava tê-la concedido sem ônus algum: Moreira e Tassoni (2007).

${ }^{5}$ Nesta perspectiva, se inserem os trabalhos de Faria (2004), Mamigonian (2004), Oliveira (1991/1992 e 1995/96), Reis (2003), Silva (2003), Soares (2000), Soares, Gomes e Farias (2005) e Slenes (1999).

${ }^{6}$ Segundo Nei Lopes (2004, p. 412), malungo significava "companheiro, camarada; nome com que os escravos africanos tratavam seus companheiros de infortúnio no navio negreiro; irmão de criação. A etimologia tradicionalmente aceita prende-se a vocábulos bantos correspondentes ao português 'barco': o quicongo lungu, o quimbundo ulungu etc. Também, o quioco malunga, plural de lunga, 'homem', 'marido', 'macho'. Interessante analisar, ainda, no quicongo, as palavras ma-lungu, plural de lingu, 'sofrimento', 'pena', 'morte', 'dificuldade'; na-lùngu, 'aquele que sofre'; e madungu, 'estrangeiro', 'pessoa desconhecida”'.

${ }^{7}$ op. cit. p. 51

${ }^{8}$ APERS, RG, Livro 12, p. 85.

${ }^{9}$ APERS, Pelotas, $1^{\circ}$ Órfãos e Provedoria, n681m42a1869.

10 "Ussá" no documento original. Além da proximidade gráfica das duas palavras, tomo como exemplo a abordagem de Reis (2003, p. 295-296). Este autor identificou o africano Elesbão do Carmo, chamado por seus patrícios de Dandara, transcrito como "ussá" no documento original como haussá.

Anos 90, Porto Alegre, v. 15, n. 27, p. 189-231, jul. 2008 
${ }^{11}$ Uma das características da escravidão urbana era a maior possibilidade para os cativos de mobilidade ou de "Viver sobre si". Sobre este assunto, ver: Mattos (1998, p. 50), Chalhoub (1990), Algranti (1988) e Karasch (2000).

${ }^{12}$ Antônio haussá e José mina divergem sobre como foi feita a divisão do dinheiro. O primeiro dizia haver pego parte da quantia, enquanto o segundo afirmava que Antônio teria posto tudo em seu chapéu e ido embora.

${ }^{13}$ Em 1857, a africana Ana, de nação Mina-Nagô, quitandeira, escrava de Maria José de Carvalho, desentendeu-se com sua comadre, a preta forra Sofia Maria da Conceição, natural de Rio Grande. A briga física das duas teria sido motivada por uma discussão iniciada quando a mina Ana foi reclamar o dinheiro que tinha dado para ser guardado por Sofia, cerca de cinco onças. Ambas registraram queixa na polícia, sendo que Ana o fez através de sua senhora. As duas acusações foram consideradas improcedentes. APERS, RG, Júri, Processo-crime n.88 e 89 m4b a1857.

${ }^{14}$ Grifos meus. Em negrito os escravos e africanos presentes. Sublinhados os valores que eles possuíam.

${ }^{15}$ A idéia de parentesco étnico que utilizo baseia-se principalmente em dois estudos sobre africanos no século XIX: Soares; Gomes; Farias (2005) e Reis (2003), especialmente parte III - A comunidade africana em revolta, p.307-417.

${ }^{16}$ No momento em que José moleque foi esconder o dinheiro nas areias, uma preta mina o viu. Esta foi contar ao senhor ao qual estava alugada no momento, o qual, juntamente com seu vizinho, recolheu parte do dinheiro furtado. Eles eram João Câncio e Joaquim Lopes de Oliveira, que acabaram sendo condenado a 2 meses e 10 dias de prisão, além de pagar 5\% sobre o valor furtado e as custas do processo.

${ }^{17}$ APERS, VFSP, Contas de testamento, n.4189m118a1857.

${ }^{18} \mathrm{O}$ africano Joaquim de Antiqueira já foi objeto de estudo anterior: Scherer (2007). ${ }^{19}$ APERS, RG, Tab., Livro 16, p. $15 \mathrm{v}$.

${ }^{20}$ APERS, RG, Tab., Livro 14, p. 27.

${ }^{21}$ Conforme o traslado da certidão de óbito, no livro de óbitos de livres e libertos à folha 73v e 74, se achava o assento seguinte: "Aos trinta e um de outubro de 1860 nesta Freguesia de S. Pedro do Rio Grande faleceu de tubérculos pulmonares o preto liberto Manoel Francisco Bento de Nação Mina liberto, casado não deixa filhos algum. Recebeu os sacramentos. Foi encomendado e sepultou-se no Cemitério desta Cidade. E para constar o presente que assinei. Vigário José Maria Damásio Mattos - Rio Grande , 3 de Novembro de 1860.”

${ }^{22}$ APERS, VFSP, Redução de testamentos, n. 4190m118a1862.

${ }^{23}$ Consta no documento "disse ser sobrinho da Justificante [...] que estando em casa de sua Tia”.

${ }^{24}$ Segundo Oliveira (1995-96 p.178), "havia uma tendência natural entre os escravos ladinos e os libertos de aproximarem-se dos recém-chegados de sua terra e os 
contatos iam-se multiplicando mesmo entre indivíduos que viviam em freguesias distantes umas das outras".

${ }^{25}$ Ainda são necessárias pesquisas sobre as relações consangüíneas entre os africanos da cidade portuária sulina. Para Salvador, os dados indicam a dificuldade de estabelecer esses laços, demonstrando que entre os libertos que fizeram testamento $70 \%$ não haviam tido filhos. (OLIVEIRA apud REIS, 2003, p. 412-413). Em Desterro os dados são provenientes dos registros de batismo, nos quais Mortari (2007, p. 99) encontrou um número de " 261 crianças legítimas filhos de africanos escravos, em relação a um total de 3.800 ilegítimas filhos de africanas solteiras".

${ }^{26}$ Conforme as palavras de Jorge sobre aquela reunião.

${ }^{27}$ Mortari (2007, p. 114) notou em Desterro que boa parte dos casais africanos se formavam com parceiros do mesmo grupo de procedência, constituindo $71,57 \%$ dos casos.

${ }^{28}$ As ocupações de escravos listados nos inventários de Rio Grande revelam que minas e nagôs eram empregados como marinheiros, carneadores, salgadores, campeiros, alfaiates, carpinteiros, ferreiros, cozinheiros, entre outras atividades.

${ }^{29}$ Expressão utilizada por Florentino (2005), e também por Soares, Gomes e Farias (2005).

${ }^{30} \mathrm{Em}$ um processo-crime em que dois cativos são acusados de roubo, o delegado de Rio Grande pergunta a um dos réus se o pretenso dinheiro furtado não teria sido empregado para a compra da alforria de uma escrava chamada Henriqueta. APERS, RG, Júri, Processo-crime, n.2m1a1837. A análise completa deste caso pode ser vista no capítulo 4 de minha dissertação de mestrado, já citada anteriormente.

${ }^{31}$ Os provenientes da região oriental da África não constam na tabela por terem uma participação muito pequena nas alforrias, com apenas seis cartas.

${ }^{32}$ Ver tabela 1.

${ }^{33}$ Isso pode ser verificado nos estudos de Faria (2004), Florentino (2005) e de Soares, Gomes e Farias (2004).

${ }^{34}$ APERS, RG, Livro 17, p. 85v.

${ }^{35}$ APERS, RG, Livro 25, p.90v.

${ }^{36}$ APERS, Pelotas, Livro 11, p. 50v. In: Documentos da escravidão: catálogo seletivo de cartas de liberdade acervo dos tabelionatos do interior do Rio Grande do Sul/ Porto Alegre: CORAG, 2006.

${ }^{37}$ O preto mina Luiz recebeu alforria do Doutor João Batista de Figueiredo Mascarenhas, em Pelotas, aos vinte dias de junho de 1855, com a condição de lhe servir ainda por mais dois anos "como engajado e vencendo o salário mensal de 8 patacões” (APERS, Pelotas, Livro 5, p. 46v). In: Documentos da escravidão..., 2006.

${ }^{38}$ APERS, RG, Livro 23, p. 87v.

${ }^{39}$ APERS, Órfãos e Provedoria, n.2240, m89, a1879.

${ }^{40}$ APERS, RG, Livro 14, p. 45. 
${ }^{41}$ APERS, Pelotas, Livro 4, p. 54v. In: Documentos da escravidão..., 2006.

\section{Referências}

ALGRANTI, Leila Mezan. O feitor ausente. Estudo sobre a escravidão urbana no Rio de Janeiro, 1808-1821. Petrópolis: Vozes, 1988.

BERUTE, Gabriel Santos. Dos escravos que partem para os portos do sul: características do tráfico negreiro do Rio Grande de São Pedro do Sul, c. 1790- c. 1825. Dissertação (Mestrado) - Universidade Federal do Rio Grande do Sul, Porto Alegre, 2006.

CHALHOUB, Sidney. Visões da liberdade: uma história das últimas décadas da escravidão na corte. São Paulo: Companhia das Letras, 1990.

FARIA, Sheila de Castro. Sinhás pretas, Damas Mercadoras: As pretas minas nas cidades do Rio de Janeiro e de São João Del Rey (1700-1850). Niterói. Tese apresentada ao Depto. de História da UFF no Concurso para Professor Titular em História do Brasil. 2004.

FLORENTINO, Manolo. Sobre Minas, Crioulos e a Liberdade Costumeira no Rio de Janeiro, 1789-1871. In: FLORENTINO, Manolo (org.). Tráfico, Cativeiro e Liberdade (Rio de Janeiro, séculos XVII-XIX). Rio de Janeiro: Civilização Brasileira, 2005.

KARASCH, Mary C. A vida dos escravos no Rio de Janeiro - 1808/1850. São Paulo: Companhia das Letras, 2000.

LOPES, Nei. Enciclopédia Brasileira da Diáspora Africana. São Paulo: Selo Negro, 2004.

MAMIGONIAN, Beatriz Galloti. África no Brasil: mapa de uma área em expansão. Topoi, v.5, n.9, p.33-53, 2004.

MATTOS, Hebe. Das Cores do Silêncio: os significados da liberdade no Sudeste escravista, Brasil Século XIX. Rio de Janeiro: Nova Fronteira, 1998.

MOREIRA, Paulo R. S.; TASSONI, Tatiani. Que com seu trabalho nos sustenta: as cartas de alforria de Porto Alegre (1748/1888). Porto Alegre: EST Edições, 2007.

MOREIRA, Paulo R. S. Lealdades Compartilhadas: Famílias Negras e Etnicidades no Espaço Urbano (Porto Alegre - Século XIX) In: PESAVENTO, Sandra (org.). Leituras de História Cultural. São Paulo: HUCITEC, 2008.

MORTARI, Cláudia. Os africanos de uma vila portuária do sul do Brasil: criando vínculos parentais e reinventando identidades. Desterro, 1788/1850. Tese (Doutorado) Pontifícia Universidade Católica do Rio Grande do Sul, Porto Alegre, 2007. 
Parentesco de nação: vestígios de uma comunidade...

OLIVEIRA, Maria Inês Côrtes de. Viver e morrer no meio dos seus: nações e comunidades africanas na Bahia do século XIX. Revista USP. São Paulo, n.28, dez/ fev. 1995-1996.

. Quem eram os 'negros da Guiné?' A origem dos africanos na Bahia. Afro-Ásia, n.19/20, 1997.

OLIVEIRA, Vinícius Pereira. De Manoel Congo a Manuel de Paula: a trajetória de um africano ladino em terras meridionais (meados do século XIX). Porto Alegre, EST edições, 2006.

REIS, João José. Rebelião escrava no Brasil: a história do levante dos malês em 1835. - edição revista e ampliada - São Paulo: Companhia das Letras, 2003.

REIS, J. J.; GOMES, F. S.; CARVALHO, M. J. M. África e Brasil entre margens: aventuras e desventuras do africano Rufino José Maria, c. 1822-1853. Estudos AfroAsiáticos, Ano 26, n. 2, 2004, p. 257-302.

RODRIGUES, Nina. Os africanos no Brasil. 4. ed. São Paulo, Ed. Nacional; Brasília, INP, 1976. 304p. ilustr. (Brasiliana, v.9)

SCHERER, Jovani de Souza. África no sul do Rio Grande negro. In: AVILA, Vladimir (org). V Mostra de pesquisa do Arquivo Público do Estado do Rio Grande do Sul. Anais: produzindo história a partir de fontes primárias. Porto Alegre: CORAG, 2007.

. Experiências de busca da liberdade: alforria e comunidade africana em Rio Grande, séc. XIX. São Leopoldo, Dissertação de Mestrado, UNISINOS, 2008. SILVA, Alberto da Costa e. Um rio chamado Atlântico: a África no Brasil e o Brasil na África. Rio de Janeiro: Nova Fronteira. Ed. UFRJ, 2003.

SLENES, Robert W. Na sen₹̧ala uma flor: esperanças e recordações na formação da família escrava, Brasil Sudeste, século XIX. Rio de Janeiro: Nova Fronteira, 1999.

. 'Malungu Ngoma vem!': África encoberta e descoberta no Brasil”. Revista USP, n.12 (1991-2), p. 48-67.

SOARES, Carlos Eugênio Líbano. Zungú: rumor de muitas vozes. Rio de Janeiro: Arquivo Público do Estado do Rio de Janeiro, 1998.

SOARES, Carlos Eugênio Líbano; GOMES, Flávio dos Santos; FARIAS, Juliana Barreto. No labirinto das nações: africanos e identidades no Rio de Janeiro. Arquivo Nacional, 2005.

SOARES, Mariza de Carvalho. Devotos da cor: identidade étnica, religiosidade e escravidão no Rio de Janeiro, século XVIII. Rio de Janeiro: Civilização Brasileira, 2000.

Anos 90, Porto Alegre, v. 15, n. 27, p. 189-231, jul. 2008 
THORNTON, John Kelly. A África e os africanos na formação do mundo atlantico, 1400-1800. Trad. de Marisa Rocha Mota. Rio de Janeiro: Elsevier, 2004.

Recebido em 29/04/2008 Aprovado em 19/08/2008 
